\title{
STUDY ON APPLICATION OF MULTIPLEX LIGATION-DEPENDENT PROBE AMPLIFICATION (MLPA) ASSAY IN MOLECULAR DIAGNOSIS OF RETINOBLASTOMA
}

\author{
Vu Phuong Nhung ${ }^{1,2}$, Nguyen Thi Thanh Hoa ${ }^{1,2}$, Ma Thi Huyen Thuong ${ }^{1}$, Tran Thi Bich Ngoc $^{1}$, Nguyen \\ Dang Ton ${ }^{1,2}$, Nguyen Thuy Duong ${ }^{1,2}$, Nong Van Hai ${ }^{1,2}$, Nguyen Hai Ha ${ }^{1,2, 凶}$ \\ ${ }^{1}$ Institute of Genome Research, Vietnam Academy of Science and Technology \\ ${ }^{2}$ Graduate University of Science and Technology, Vietnam Academy of Science and Technology
}

To whom correspondence should be addressed. E-mail: nguyenhaiha@igr.ac.vn

Received: 20.11 .2017

Accepted: 28.12.2017

\section{SUMMARY}

Retinoblastoma $(\mathrm{Rb})$ is a malignant retinal tumor on young children which is often founded before the age of 5. This cancer disease appears when both of $R B 1$ alleles on 13q14.2 chromosome are mutated. The aim of this research is to evaluate the ability of Multiplex Ligation-dependent Probe Amplification (MLPA) in screening of $R B 1$ gene insertion/deletions in Vietnamese patients with Rb. Genomic DNA was isolated from peripheral blood of the research subjects and subsequently analyzed by MLPA technique. To prove the results of MLPA, quantitative real-time PCR was used for determining the RB1 gene copy number for all samples. Two significant deletion mutations were identified on two different $\mathrm{Rb}$ patients, one is the deletion from exon 4 to exon 27 recorded on KVM38 sample, and the other is the complete removal of an allele on KVM21 sample. The MLPA showed a complete correlation with real-time PCR results. These are the disease causing mutations, can be inherited and they are important evidences for genetic counseling and clinical management. Those results have proven the high speed and reliability of MLPA method in identifying deletion/duplication mutations on $\mathrm{Rb}$ patients.

Keywords: Retinoblastoma, deletions/duplications mutation, RB1 gene, MLPA, genetic counseling

\section{INTRODUCTION}

Retinoblastoma $(\mathrm{Rb})$ is a malignant retinal tumor caused by mutations in both alleles of the $R B 1$ gene and often encountered in young children under 5 years old. This tumor appears on both sexes with the ratio ranging from $1 / 15000$ to $1 / 20000$ regardless the races (Kivelä, 2009; Vogel, 1979). Approximately $40 \%$ of patients are heritable, and $60 \%$ cases are non-heritable $\mathrm{Rb}$ (Gao, et al., 2011). Both types of $\mathrm{Rb}$ are caused by the inactivation of both alleles of tumor suppressing genes $R B I$ which are located on chromosome 13 (Dimaras, et al., 2012). Heritable form of $\mathrm{Rb}$ is caused by first germinal mutation and the second one acquired in the somatic retina cells. RB1 protein plays an important role in regulating cell proliferation and differentiation, it involves in G1/S transition by inhibiting E2F transcription factors which are necessary to active $\mathrm{S}$ phase. The inactivation of $R B 1$ has the most significant impact on a group of cone cell precursors in the development of retina. The high expression of $R B 1$ gene in these cell groups proves its important role in the regulation of cell proliferation ( $\mathrm{Xu}$ et al., 2009). Mutations in the $R B 1$ gene are highly heterogeneous and scattered in the promoter and the 27 exons. To date, more than 1600 distinct mutations, ranging from small mutations to large deletions, have been registered in the RB1 Gene Mutation Database (He et al., 2014). Every year, Vietnam National Institute of Ophthalmology diagnosed about 40 new cases of $\mathrm{Rb}$. Most of the cases, patients were hospitalized in the late stage and missed the chance of saving their eyes. Among those cases, the majority of patients were born in a family with Retinoblastoma anamnesis which indicated a tight relationship between heredity and this disease. In 2005, Nguyen Cong Kiet and Nguyen Tri Dung had studied about inherited characteristic of $30 \mathrm{RB} 1$ cases in Viet Nam. Using karyotyping method, this research group had 
identified only one case that had a deletion on 13q14 chromosome (Cong Kiet N, Dung Tri N, 2005). In 2014, Nguyen Hai Ha and colleagues had identified two mutations in $R B 1$ gene of 2 children with $\mathrm{Rb}$ (Hai Ha N et al., 2014). In 2016, Nguyen Hai Ha and colleagues had combined DNA and cDNA analysis in screening of $R B 1$ gene mutation of a family with $\mathrm{Rb}$. The result has shown that the healthy father and his two affected children carried a mutation resulting in aberrant $R B 1$ pre-mRNA splicing. In the developed countries, $R B 1$ gene testing has become a periodic test on $\mathrm{Rb}$ patients (Robson et al., 2015), due to $R B 1$ mutation is a source of evidences for genetic counseling and clinical management. In Vietnam, although a high amount of budget has been invested for the development of clinical treatment technique, the development of molecular technique for early diagnose of $\mathrm{Rb}$ is almost still left open.

About $15 \%-25 \%$ of mutations detected in $\mathrm{Rb}$ cases were large deletion/duplication on $R B 1$ gene (Ahani et al., 2011). Due to the limitation of Sanger sequencing that allows only the detection of missense mutation, small deletion/duplication, combining multiple technique to identify large deletion/duplication on $R B 1$ gene is necessary. From 2002, Multiplex Ligation dependent Probe Amplification (MLPA) had been accepted as sufficiently sensitive technique for detecting copy number (gain or loss) of a single exon of human gene (Schouten, et al., 2002). This is a high throughput method developed to identify copy number of up to 50 DNA sequences using a multiplex PCR reaction. To date, the information of MLPA application in genetic testing for RB1 in Vietnam is still unknown. The present study aims to evaluate MLPA for detecting deletion/duplication mutations in molecular diagnosis of $\mathrm{Rb}$. From here, it is more possible to avoid deficiencies in diagnosis and the data for genetic counseling for the patient's family will be more complete.

\section{MATERIALS AND METHODS}

\section{Study subjects}

This study selected DNA samples from 4 children, one is a healthy child (REF) and three children (KVM21, KVM22 and KVM23) diagnosed with $\mathrm{Rb}$ by ophthalmologists from the Vietnam National Institute of Ophthalmology, Hanoi, Vietnam (Table 1). All of these samples were negative with $R B 1$ gene point mutations screening by direct sequencing method. The research has been conducted at the Institute of Genome Research, Vietnam Academy of Science and Technology.

Table 1. Summary of patient's disease status

\begin{tabular}{lllll}
\hline \multirow{2}{*}{ Sample's ID } & Sex & \multicolumn{2}{c}{ Tumor location } & Family anamnesis \\
\cline { 3 - 4 } & & Left eye & Right eye & \\
\hline REF & Female & No & No & No \\
KVM21 & Male & Yes & Yes & Affected Father \\
KVM22 & Female & Yes & Yes & No \\
KVM38 & Female & Yes & Yes & No \\
\hline
\end{tabular}

\section{Genomic DNA isolation}

Peripheral blood from patients and healthy people were stored in EDTA tubes in $-20^{\circ} \mathrm{C}$ fridge until use. We used E.Z.N.A Blood DNA mini kit (Promega) to extract genomic DNA from peripheral blood samples according to the manufacturer's protocol. After purification, genomic DNA samples were quantified by Qubit Fluorometer BR DNA kit (Broad-range). Fluorescent signal from the dye is proportional with concentration of bound DNA. From here, qubit fluorometer will receive the signal and calculate double stranded DNA concentration based on the standard curve built from standard samples (included in the kit).

\section{Multiplex ligation-dependent probe amplification (MLPA) assay}

To identify deletions/duplications on $R B 1$ gene, MPLA technique was performed using SALSA MLPA P047-D1 RB1 Probemix kit (MRC-Holland, Amsterdam, Netherlands) following the manufacturer's protocol. P047-D1 $R B 1$ probemix contain the probes for 26 over 27 $R B 1$ 's exons. There is not any probe for exon 15 since it is located very close to the adjacent exons. 
Furthermore, this probemix contains several probes for $R B 1$ gene's junctions (48 kb upstream and $35 \mathrm{~kb}$ downstream of the gene) as well as one probe for $D L E U 1$ gene and two probes for $P C D H 8$ gene at the rear of $R B 1$ gene which are located 1.6 $\mathrm{Mb}$ and $4.5 \mathrm{Mb}$, respectively. To prepare for MLPA reaction, total DNA was diluted to the concentration of $10 \mathrm{ng} / \mu 1$ in TE 0.1 . Fifty $\mathrm{ng}$ of genomic DNA with a total volume of $5 \mu \mathrm{l}$ was denatured and hybridized with SALSA probemix, following by incubation at $60^{\circ} \mathrm{C}$ for $16-20 \mathrm{~h}$. Subsequently, the annealed probes were ligated using Ligase 65 at $54^{\circ} \mathrm{C}$ for $5 \mathrm{~min}$. In the next step, all ligated products were used as template for DNA amplification. The amplicons were run on Genetic Analyzer 3500 (Applied Biosystems, Foster City, CA). The collected data was analyzed by Coffalyzer.net software. Subject having normal copy number was expected to produce a normalized signal value ratio of $0.8-1.2,0.65$ and 1.3 were used as cut-off values for heterozygous deletion and heterozygous duplication, respectively.

\section{Real-time PCR assay}

Gene dosage of different samples was performed with relative quantification real-time PCR method. Real-time PCR reaction was performed using Luna Universal qPCR Master Mix (M3003-NEB) and primers used for quantitative analysis of $R B 1$ gene were referred to Ahani's study (RB1-RT-E7, RB1RT-E22, and RPPH1, a reference gene with single copy) (Ahani et al., 2013). The copy numbers of each exon in comparison to reference gene was determined according to equation: $\Delta \Delta \mathrm{Ct}=\mathrm{CtRPPH} 1$ (reference sample)CtRB1exon(reference sample)-[CtRPPH1(unknown sample)- CtRB1exon(unknown sample)]. Then the relative copy numbers of the gene were calculated following ratio equation $\left(2^{-\Delta \Delta \mathrm{Ct}}\right)$. The expected values were about 1 for normal coy number, 0.5 for heterozygous deletions and 1.5 for heterozygous duplications.

\section{RESULTS AND DISCUSSION}

\section{Identification of $R B 1$ gene deletions/duplications by MLPA assay}

The genomic DNA concentrations from three $\mathrm{Rb}$ affected children and a healthy child, as a reference sample, were ranging from 20 to 37.5 $\mathrm{ng} / \mu \mathrm{l}$ (Table 2). Electrophoresis of total DNA product on agarose gel showed clear and bright bands (data not shown), indicated that the product was not broken and reached purification level for the next experiment. As a result, heterozygous deletions were found in KVM21 (whole gene) and KVM38 (partially from exon 4 to exon 27) while KVM22 did not have any abnormal copy number compared to reference sample. The DQ values of KVM21 (exon 1-27) and KVM38 (exon 4-27) ranging from $0.44-0.6$ and $0.41-0.67$, respectively. In KVM21, the signal peaks of exon 1 to 27 were all half lower than the control samples (Figure 1AB). Similar signal peaks pattern was observed from exon 4 to exon 27 of KVM38 (Fig. 1D). For KVM22, DQ value of all probes were about 0.81.2 similar to the control samples, indicating there were not any large deletion/duplication appear in the $R B 1$ gene of this patient. The electropherogram of KVM22 was also illustrated the peaks with corresponding height to that of control samples (Fig. 1C).

Table 2. Result of total DNA quantification.

\begin{tabular}{ll}
\hline Sample & Concentration $(\mathbf{n g} / \mathbf{\mu l})$ \\
\hline REF & 37.5 \\
KVM21 & 34.1 \\
KVM22 & 22.2 \\
KVM38 & 20 \\
\hline
\end{tabular}

\section{Identification of $R B 1$ gene deletions/duplications by real-time PCR assay}

Real-time PCR is a high throughput technique for determining gene copy number by measuring of PCR amplicon accumulation in real time. This study conducted real-time PCR as an additional method to validate the MLPA results. DNA samples of 3 patients and 1 healthy child above were applied to real-time PCR assay using specific primer pairs for exon 7 and exon 22 of $R B 1$ gene. The comparative analysis results showed that the copy numbers (presented as $2^{-\Delta \Delta \mathrm{Ct}}$ value) of exon 7 and exon 22 of KVM22 sample was equal to those of reference sample while the copy numbers of KVM21 and KVM38 were less than one-haft when comparing to the reference sample (Fig. 2). Those results correlated completely with MLPA results. 

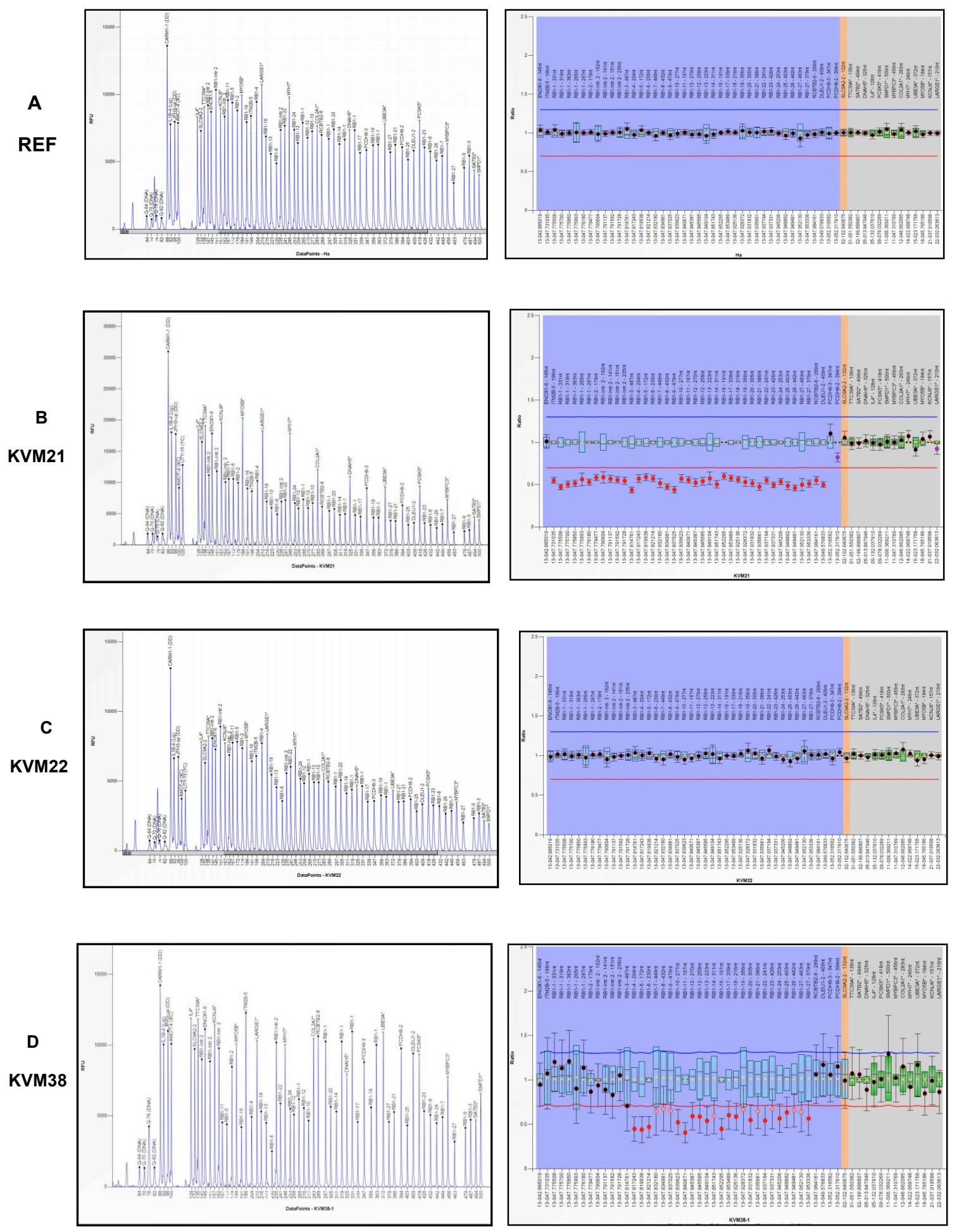

Figure 1. Electrophotogram of MLPA. KVM: patient samples; REF: healthy control sample. 


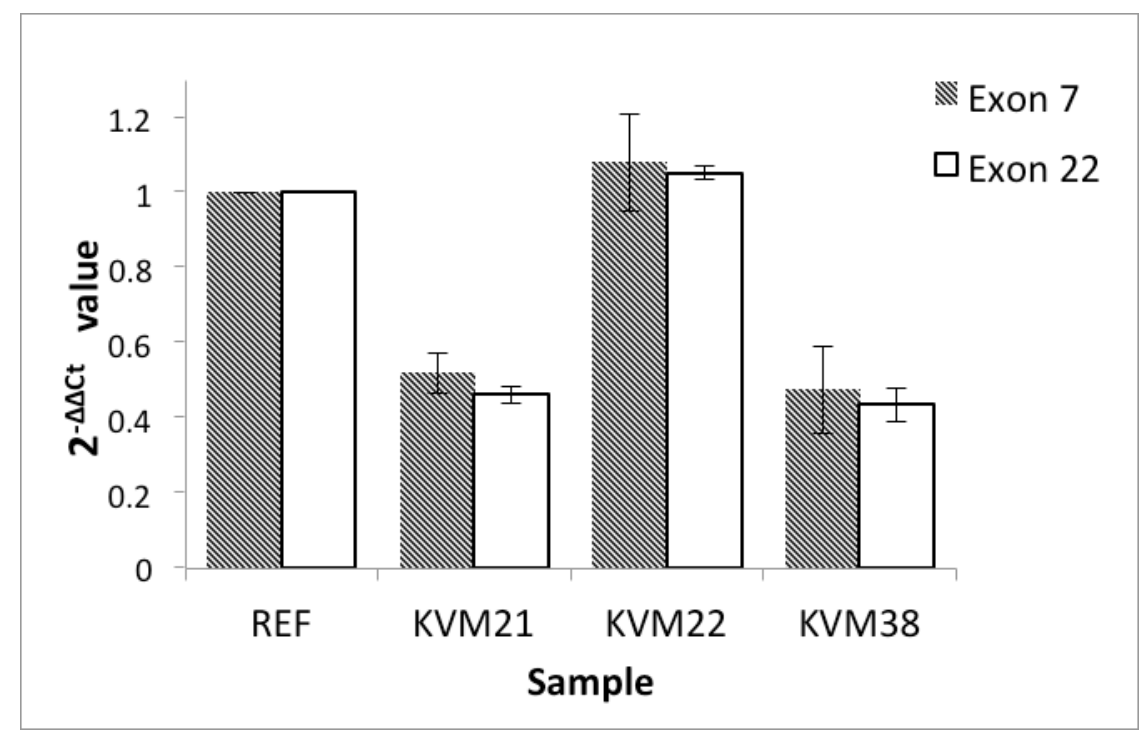

Figure 2. Real-time PCR results. The copy numbers of the exon 7 and exon 22 from each sample was compared to reference gene RPPH1. KVM; patient samples; REF; healthy control sample.

Screening $R B 1$ genetic mutations is a critical step in clinical management as well as genetic counseling for patient's family. Previously, gross rearrangements of $R B 1$ gene can be detected by several techniques such as karyotype, G-banding, FISH, QFM-PCR (quantitative fluorescent multiplex polymerase chain reaction), MLPA and real-time PCR (Houdayer et al., 2004; Lohmann et al., 1992; Lohmann et al., 1994; Zielinski et al., 2005). However, karyotype and FISH can only recognize huge re-combination such as the deletion of a whole genome. Real-time PCR has a high accuracy but is hard to carry out a high throughput in one single run. MPLA and QFM-PCR has an advantage that allows reading the whole gene in one reaction. QFM-PCR can usually have technical problem, has relatively low throughput and low-reproductively, while MLPA is easier to carry out because all the necessary reagents and probes are commercially available. Furthermore, MLPA is technically uncomplicated and suitable for processing large number of samples with short turnaround time. Some research results showed that combining sequencing and MLPA had increased the sensitivity of diagnosis. Specifically, a research from China demonstrated that the rate of mutation detection had increased from $78.6 \%$ (only Sanger sequencing) to 92.3\% (combined sequencing with MLPA) (He et al., 2014). Research on Malaysian patients had also reported that the rate of mutation recognition is
$52.6 \%$ (combine sequencing with MLPA), higher than that of sequencing only (36.8\%) and MLPA only (15.8\%) (Mohd Khalid et al., 2015). Direct sequencing of $R B I$ exons and intron boundary regions combine with detection of large deletion/duplication by using MLPA is a standard method for identifying germline mutations. In this research, we have found $2 / 3$ of children with $\mathrm{Rb}$ having large deletion on $R B 1$ gene, one had a complete loss of one allele and one had a partial deletion from exon 4-27 of $R B 1$ gene. These are germinal mutations, both of them had tumor developed in both eyes. For the KVM22 sample, both DNA sequencing and MLPA method could not identify any germline mutation in $R B 1$ gene despite this child is bilateral. This issue can be explained by three hypotheses. First, this patient carries mutations on both of the RBI alleles but it only appeared during the development of retina, these are somatic mutations and are not inheritable. In this case, $R B 1$ gene mutations in patient tumor can be continued to analyze. Second, this child carries mutations in $R B 1$ gene but in the somatic form which occurred during embryonic development so that not all cells in the body were mutated, thus the mutation could not be found in peripheral blood sample. In order to accurately detect somatic mutation, high sensitivity methods are required such as allele specific amplification or next generation sequencing (Chen et al., 2014). Third, this patient is unlikely to carry 
any mutation in $R B 1$ gene, as this is reasonable since some previous studies have implied that somatic mutations in some other genes can also responsible for the formation and development of retina tumor (Kooi et al., 2016).

We have succeeded in approaching analysis of $\mathrm{Rb}$ patient samples in order to identify deletions/duplications in $R B 1$ gene by MLPA method. This research has contributed to build up a more comprehensive genetic analysis of $\mathrm{Rb}$ patients in Vietnam. Survivors of hereditary retinoblastoma have increased risk of developing other cancers later in life. Therefore, the collected results are an important source of evidences for clinical management and genetic counseling for patient's family as well as prognosis for the occurrence of tumors on other organs of RB patients, for instance, osteosarcoma and melanoma.

\section{CONCLUSION}

We were successful in identifying 2 of $3 \mathrm{Rb}$ patients with large heterozygous deletion mutations in RBI gene. The collected results indicated that MLPA is a fast, reliable and powerful method to assess the deletions/duplications of $R B 1$ gene in patients with retinoblastoma. The results of this study contribute to the improvement of molecular analysis and technique in diagnosis of Retinoblastoma in Vietnam.

Acknowledgements: This research is funded by the Institute of Genome Research (Grant No.21/QDNCHG, Vietnam Academy of Science and Technology.

\section{REFERENCES}

Ahani A, Behnam B, Khorram Khorshid HR, Akbari MT (2011) RB1 Gene mutations in Iranian patients with retinoblastoma: report of four novel mutations. Cancer Genet 204(6): 316-322.

Ahani A, Akbari MT, Saliminejad K, Behnam B, Akhondi MM, Vosoogh P, Ghassemi F, Naseripour M, Bahoush G, Khorshid HRK (2013) Screening for large rearrangements of the RB1 gene in Iranian patients with retinoblastoma using multiplex ligation-dependent probe amplification. Mol Vis 19: 454-462.

Chen Z, Moran K, Richards-Yutz J, Toorens E, Gerhart D, Ganguly T, Shields CL, Ganguly A (2014) Enhanced
Sensitivity for Detection of Low-Level Germline Mosaic RB1 Mutations in Sporadic Retinoblastoma Cases Using Deep Semiconductor Sequencing. Hum Mutat 35(3): 384391.

Cong Kiet N, Dung Tri N (2005) Heritance characteristcs of Retinoblastoma. Medicine Journal of Ho Chi Minh City 9: 99-103.

Dimaras H, Kimani K, Dimba EAO, Gronsdahl P, White A, Chan HSL, Gallie BL (2012) Retinoblastoma. The Lancet 379(9824): 1436-1446.

Gao YJ, Qian J, Yue H, Yuan YF, Xue K, Yao YQ (2011) Clinical characteristics and treatment outcome of children with intraocular retinoblastoma: A report from a Chinese cooperative group. Pediatr Bood Cancer 57(7): 11131116.

Hai Ha N, Manh Hung D, Thuy Quynh L, Thuy Duong N, Dang Ton N (2014) Identification of RB1 gene mutation in young children suffering Retibnoblastoma. J Biotechnol 12(1): 23-29. (in Vietnamese)

He M, An Y, Gao Y, Qian X, Li G, Qian J (2014) Screening of RB1 gene mutations in Chinese patients with retinoblastoma and preliminary exploration of genotypephenotype correlations. Mol Vis 20: 545-552.

Houdayer C, Gauthier-Villars M, Laugé A, PagèsBerhouet S, Dehainault C, Caux-Moncoutier V, Karczynski P, Tosi M, Doz F, Desjardins L, Couturier J, Stoppa-Lyonnet D (2004) Comprehensive screening for constitutional RB1 mutations by DHPLC and QMPSF. Hum Mutat 23(2): 193-202.

Kivelä T (2009) The epidemiological challenge of the most frequent eye cancer: retinoblastoma, an issue of birth and death. Br J Ophthalmol 93(9): 1129-1131.

Kooi IE, Mol BM, Massink MPG, de Jong MC, de Graaf P, van der Valk P, Meijers-Heijboer H, Kaspers GJL, Moll AC, te Riele H, Cloos J, Dorsman JC (2016) A MetaAnalysis of Retinoblastoma Copy Numbers Refines the List of Possible Driver Genes Involved in Tumor Progression. Plos One 11(4): e0153323.

Lohmann D, Horsthemke B, Gillessen-Kaesbach G, Stefani FH, Höfler H (1992) Detection of small RB1 gene deletions in retinoblastoma by multiplex PCR and highresolution gel electrophoresis. Hum Genet 89(1): 49-53.

Lohmann DR, Brandt B, Höpping W, Passarge E, Horsthemke B (1994) Spectrum of small length germline mutations in the RB1 gene. Hum Mol Genet 3(12): $2187-$ 2193.

Mohd Khalid MKN, Yakob Y, Md Yasin R, Wee Teik K, Gaik Siew Cn, Rahmat J, Ramasamy S, Alagaratnam J (2015) Spectrum of germ-line RB1 gene mutations in Malaysian patients with retinoblastoma. Mol Vis 21: 11851190. 
Robson ME, Bradbury AR, Arun B, Domchek SM, Ford JM, Hampel HL, Lipkin SM, Syngal S, Wollins DS, Lindor NM (2015) American Society of Clinical Oncology Policy Statement Update: Genetic and Genomic Testing for Cancer Susceptibility. J Clin Oncol 33(31): 3660-3667.

Schouten JP, McElgunn CJ, Waaijer R, Zwijnenburg D, Diepvens F, Pals G (2002) Relative quantification of 40 nucleic acid sequences by multiplex ligation-dependent probe amplification. Nucleic Acids Res 30(12): e57-e57.

Vogel F (1979) Genetics of retinoblastoma. Hum Genet 52(1): $1-54$.
Xu XL, Fang Y, Lee TC, Forrest D, Gregory-Evans C, Almeida D, Liu A, Jhanwar SC, Abramson DH, Cobrinik D (2009) Retinoblastoma Has Properties of a Cone Precursor Tumor and Depends Upon Cone-Specific MDM2 Signaling. Cell 137(6): 1018-1031.

Zielinski B, Gratias S, Toedt G, Mendrzyk F, Stange DE, Radlwimmer B, Lohmann DR, Lichter P (2005) Detection of chromosomal imbalances in retinoblastoma by matrix-based comparative genomic hybridization. Genes Chromosomes Cancer 43(3): 294-301.

\title{
NGHIÊN CÚU ÚNG DỤNG KỸ THUẬT KHUẾCH ĐẠI ĐẦU DÒ ĐA MỒI (MLPA) TRONG CHẨN ĐOÁN PHÂAN TỬ BỆNH U NGUYÊN BÀO VÕNG MẠC
}

\author{
Vũ Phương Nhung ${ }^{1,2}$, Nguyễn Thị Thanh Hoa ${ }^{1,2}$, Ma Thị Huyền Thương ${ }^{1}$, Trần Thị Bích Ngọc ${ }^{1}$, \\ Nguyễn Đăng Tôn ${ }^{1,2}$, Nguyễn Thùy Dương ${ }^{1,2}$, Nông Văn Hải ${ }^{1,2}$, Nguyễn Hải Hà ${ }^{1,2}$ \\ ${ }^{I}$ Viện Nghiên cứu hệ gen, Viện Hàn lâm Khoa học và Công nghệ Việt Nam \\ ${ }^{2}$ Học viện Khoa học và Công nghệ, Viện Hàn lâm Khoa học và Công nghệ Việt Nam
}

\section{TÓM TẮT}

U nguyên bào võng mạc $(\mathrm{Rb})$ là bệnh mắt ác tính ở trẻ em, thường biểu hiện trước 5 tuổi. Bệnh phát triển khi cả 2 alen của gen $R B 1$ trên 13q14.2 bị đột biến. Mục tiêu của nghiên cứu này là đánh giá khả năng sử dụng phương pháp MLPA (khuếch đại đầu dò đa mồi) để phát hiện các đột biến mất đoạn/lặp đoạn trên gen $R B 1$ ở những bệnh nhi u nguyên bào võng mạc Việt Nam. DNA tổng số được tách chiết từ máu ngoại vi của các bệnh nhi và được phân tích bằng phương pháp MLPA. Để kiểm định kết quả phân tích gen của MLPA, số lượng bản sao gen $R B 1$ của các mẫu nghiên cứu đã được xác định bằng phương pháp real-time PCR định lượng. Hai đột biến mất đoạn lớn được phát hiện trên bệnh nhi KVM21 (mất toàn bộ 1 alen $R B 1$ ) và KVM38 (mất từ exon 4 đến exon 27). Kết quả thu được từ MLPA hoàn toàn phù hợp với kết quả kiểm tra bằng real-time PCR. Đây là những đột biến gây bệnh và di truyền được, do đó thông tin về những đột biến này rất có ý nghĩa đối với tư vấn di truyền và quản lý lâm sàng. Kết quả từ nghiên cứu này cho thấy MLPA là phương pháp nhanh chóng và đáng tin cậy trong việc phát hiện những đột biến mất đoạn/lặp đoạn ở bệnh nhi u nguyên bào võng mạc.

Từ khóa: U nguyên bào võng mạc, đột biến mất đoạn/lạp đoạn, gen RB1, MLPA, tư vấn di truyền 